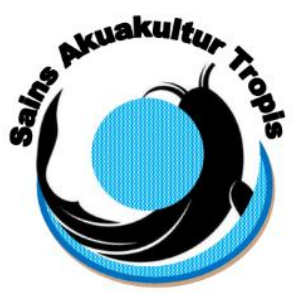

\author{
Jurnal Sains Akuakultur Tropis \\ Departemen Akuakultur \\ Fakultas Perikanan dan IImu Kelautan - Universitas Diponegoro \\ Jl. Prof. Soedarto, SH, Tembalang, Semarang 50275 \\ Telp. (024) 7474698, Fax.: (024) 7474698 \\ Email: sainsakuakulturtropis@gmail.com, sainsakuakulturtropis@undip.ac.id
}

\title{
PENGARUH PEMBERIAN TEPUNG CACING TANAH (Lumbricus Sp.) SEBAGAI ATRAKTAN DALAM PAKAN TERHADAP TINGKAT KONSUMSI PAKAN, EFISIENSI PAKAN DAN PERTUMBUHAN IKAN PATIN (Pangasius sp.)
}

The Effect of Earthworm Meal (Lumbricus sp.) as an Attractant on Feed Consumption Level, Feed Eficiency and Growth of Catfish (Pangasius sp.)

\section{Rizkiana Amalia, Sri Hastuti*), Agung Sudaryono}

Departemen Akuakultur, Fakultas Perikanan dan Ilmu Kelautan,

Jl. Prof. Soedarto, SH, Tembalang, Semarang, Jawa Tengah -50275, Telp/Fax. +62247474698

* Corresponding author: hastuti_hastuti@yahoo.com

\begin{abstract}
ABSTRAK
Ikan patin (Pangasius sp) merupakan ikan konsumsi unggulan dan ditargetkan produksinya akan meningkat setiap tahun. Ikan patin memiliki nilai efisiensi pakan rendah yang meyebabkan pertumbuhan ikan patin kurang optimal, sehingga perlu adanya penambahan bahan tertentu kedalam pakan agar ikan tertarik untuk memakan pakan yang diberikan. Penggunaan tepung cacing tanah sebagai atraktan diharapkan mampu meningkatkan tingkat konsumsi pakan, efisiensi pakan dan pertumbuhan ikan patin. Penelitian ini bertujuan untuk mengkaji pengaruh pemberian tepung cacing tanah sebagai atraktan dalam pakan terhadap tingkat konsumsi pakan, efisiensi pakan dan pertumbuhan ikan patin (Pangasius sp.). Ikan patin yang digunakan memiliki rata-rata bobot awal individu 6,78 $\pm 0,68$ g/ekor. Ikan dipelihara selama 42 hari pada wadah akuarium dengan padat tebar 1 ekor/2l. Rancangan percobaan yang digunakan adalah rancangan acak lengkap dengan 4 perlakuan dan 3 ulangan. Perlakuan dengan penambahan tepung cacing tanah (Lumbricus sp.) sebagai atraktan dengan dosis 0\%, 5\%, 10\% dan 15\% dalam pakan. Hasil penelitian menunjukkan bahwa tepung cacing tanah (Lumbricus sp.) memberikan pengaruh nyata $(\mathrm{P}<0,05)$ terhadap TKP $(159,73 \mathrm{~g})$, EPP $(81,06 \%)$, PER $(2,31 \%)$, G (9,76 g) dan SGR (1,97\%/hari), dan tidak berpengaruh nyata $(\mathrm{P}>0,05)$ terhadap kelulushidupan $(84,44-93,33 \%)$. Uji kesukaan makan terbaik pada perlakuan $\mathrm{C}$ dosis $10 \%$ tepung cacing tanah dengan persentase sebesar $44 \%$ ikan yang mendekati pakan. Parameter kualitas air selama penelitian berada pada kisaran yang layak untuk kehidupan ikan patin (Pangasius sp.) yaitu suhu 27,70$30,90^{\circ} \mathrm{C}$; pH 7,00; DO 5,37-5,52 mg/l dan $\mathrm{NH}_{3}$ 0,0036-0,0095 mg/l. Pakan yang mengandung $10 \%$ atraktan tepung cacing tanah menghasilkan tingkat konsumsi pakan, efisiensi pakan dan pertumbuhan ikan patin terbaik.
\end{abstract}

Kata kunci: Atraktan; Lumbricus sp.; Pakan; Pertumbuhan; Pangasius sp.

\section{ABSTRACT}

Catfish (Pangasius sp.) is a dominant consumption fish and it is targeted that production will be increase every year. Catfish have a low feed efficiency value which is causes the growth of catfish to be less optimal, so it is necessary to add ingredient into the diets so that the fish are interested in eating the diets given. The use of earthworm meal as an attractant was expected to increase of feed consumption, feed efficiency and growth of catfish. This experiment aimed to study the effect of dietary earthworm meal as an attractant on feed consumption level, feed efficiency and growth of catfish (Pangasius sp.). The catfish used with an initial average body weight of 6,78 $\pm 0,68 \mathrm{~g} / \mathrm{fish}$. The fishes were cultured in the aquarium for 42 days with the stocking dencity of $1 \mathrm{fish} / 2 \mathrm{l}$. The experimental method used was completely randomize design (RCD) with 4 treatments and 3 replicates. The treatments were addition of earthworm meal (Lumbricus sp.) as an attractant with a dose of 0\%, 5\%, 10\% and $15 \%$ in the diets. The data showed that the use of earthworm meal (Lumbricus sp.) inclusion in the diets resulted in significant effects $(P<0,05)$ on feed consumption (159,73 g), FE (81.06\%), PER (2,31\%), G (9,76 g) and SGR $(1,97 \% / d a y)$ but not significant effect $(P>0,05)$ on survival rate $(84.44-93,33 \%)$. The best food preference test in treatment $C$ dose $10 \%$ of earthworm meal with percentage $44 \%$ fish approaching diets. The water quality 
parameters during this study varied between suitable range for the catfish (Pangasius sp.) life, i.e temperatures 27,70-30,90 $\mathrm{C} ; \mathrm{pH}$ 7,00; DO 5,37-5,52 $\mathrm{mg} / \mathrm{l}$ and $\mathrm{NH}_{3}$ 0,0036-0,0095 $\mathrm{mg} / \mathrm{l}$. It was concluded that catfish (Pangasius sp.) fed with the diet containing $10 \%$ attractants of earthworm meal resulted in better feed consumption, feed efficiency and growth.

Keywords: Attractant, Lumbricus sp., Feed, Growth, Pangasius sp.

Article Received: 14-12-2018; Accepted: 10-01-2019

\section{PENDAHULUAN}

Ikan patin (Pangasius sp.) merupakan ikan konsumsi budidaya ikan air tawar unggulan. Keunggulan ikan patin (Pangasius sp.) antara lain dagingnya yang gurih, kandungan lemak yang tinggi, dan tidak banyak duri. Harganya yang stabil dan cukup tinggi membuat usaha budidaya ikan patin ini menjanjikan keuntungan (Rachmawati dan Samidjan, 2013). Kebutuhan pasar ikan patin yang tinggi menyebabkan ikan patin banyak dibudidayakan. Namun, pakan yang diberikan untuk ikan patin kurang dimanfaatkan dengan baik sehingga berdampak pada pertumbuhan. Menurut Setiawati et al. (2013), ikan patin yang diberi pakan dengan pelet komersial memiliki nilai efisiensi pakan sebesar 50,05\%. Oleh karena itu, penambahan atraktan pada pakan dapat mempercepat pertumbuhan dan meningkatkan nafsu makan ikan patin.

Cacing tanah dapat digunakan sebagai atraktan, selain digunakan sebagai sumber bahan penyusun pakan karena mengandung asam amino bebas yang cukup lengkap. Penggunaan atraktan dalam pakan hanya dibutuhkan dalam jumlah sedikit. Menurut Evans et al. (2014), cacing tanah mengandung asam amino bebas yang cukup lengkap, diantaranya yang merupakan jenis asam amino yang berupa zat atraktif adalah seperti glisin, valin, dan lain sebagainya. Beberapa jenis asam amino seperti glisin, proline, dan valin memberikan respon makan yang lebih sensitif. Penggunaan bahan atraktan yang tepat dalam pakan dapat meningkatkan penyerapan makanan secara cepat, mengurangi waktu pencampuran nutrisi pakan dengan air saat pakan berada dalam air, dan pada saat yang sama memberikan nutrisi tambahan untuk protein dan metabolisme energi.

Beberapa penelitian yang pernah dilakukan pada tepung cacing tanah dalam pakan sebagai atraktan digunakan untuk ikan gabus (Ophiocephalus striatus) dosis terbaik 10\% (Evans et al., 2014). Tepung cacing tanah juga digunakan sebagai suplemen ikan pedang (Xiphophorus hellerii) dosis optimal 10\% (Boaru et al., 2016). Penelitian ini mengacu pada penelitian Evans et al. (2014), pada ikan gabus (O.striatus) konsentrasi terbaik tepung cacing tanah adalah $10 \%$ sehingga tepung cacing tanah dalam pakan sebagai atraktan dapat mempengaruhi tingkat konsumsi pakan, efisiensi pakan dan pertumbuhan ikan patin (Pangasius sp.).

Penelitian ini bertujuan untuk mengkaji pengaruh dan mengetahui dosis optimum pemberian tepung cacing tanah dalam pakan sebagai atraktan terhadap tingkat konsumsi pakan, efisiensi pakan dan pertumbuhan ikan patin (Pangasius sp.). Penelitian ini dilaksanakan pada April hingga Juni 2018 di Balai Benih Ikan Siwarak, Ungaran, Kabupaten Semarang, Jawa Tengah.

\section{MATERI DAN METODE}

Ikan uji yang digunakan dalam penelitian ini merupakan ikan patin dengan bobot rata-rata 6,78 $\pm 0,68 \mathrm{~g}$ berasal dari petani Ngrajek, Magelang, Jawa Tengah. Jumlah ikan yang ditebar untuk tiap perlakuan dan ulangan sebanyak 1 ekor/21 air (Beauty et al., 2012). Ikan patin yang digunakan sebanyak 180 ekor dan dibagi menjadi empat perlakuan dengan masing-masing tiga kali ulangan serta 60 ekor untuk enam perlakuan uji kesukaan makan.

Penelitian ini menggunakan dua sistem wadah pemeliharaan yaitu untuk pertumbuhan dan uji kesukaan makan. Wadah yang digunakan yaitu berupa akuarium dengan ukuran $(55 \times 45 \times 35) \mathrm{cm}^{3}$ yang diisi air 301 sebagai unit perlakuan dan setiap akuarium dipasang aerasi. Media pemeliharaan dalam penelitian ini menggunakan air tawar. Air tersebut telah diendapkan terlebih dahulu pada bak tandon selama 3 hari, dalam bak tandon dilengkapi aerasi. Setelah air diendapkan, kemudian disaring dan dipindahkan kedalam wadah pemeliharaan yang berjumlah 12 buah, dengan masing-masing kapasitas 301 air. Wadah pengamatan uji kesukaan makan berjumlah 6 buah, dengan kapasitas 201 yang berisi 10 ekor/akuarium.

Pakan yang digunakan dalam penelitian ini adalah pakan buatan berbentuk pelet. Bahan baku dalam pembuatan pelet adalah pelet komersial sebagai bahan utama, tepung cacing tanah sebagai atraktan dan sumber protein, tepung terigu dan CMC. Pakan yang diberikan pada ikan uji yaitu pakan dengan penambahan tepung cacing tanah sebagai atraktan dalam pakan. Persentase tepung cacing tanah yang ditambahkan yaitu $0 \%, 5 \%, 10 \%$ dan $15 \%$, penentuan dosis mengacu pada penelitian Evans et al. (2014), dengan hasil penelitian penambahan tepung cacing tanah dengan dosis optimal yaitu sebanyak 10\%. Pemberian pakan dilakukan secara at satiation dengan frekuensi sebanyak 2 kali yaitu pada pagi dan sore hari (08.00 dan $16.00 \mathrm{WIB})$. Komposisi bahan pakan dan analisis proksimat pakan uji yang digunakan selama 42 hari pengamatan dapat dilihat pada Tabel 1. 
Tabel 1. Komposisi bahan pakan dan Analisis Proksimat Pakan Uji (\% Bobot Kering)

\begin{tabular}{lcccc}
\hline & \multicolumn{4}{c}{ Komposisi Pakan $(\mathrm{g} / 100 \mathrm{~g}$ Pakan $)$} \\
\cline { 2 - 5 } & $\begin{array}{c}\text { Tepung Cacing } \\
\text { Tanah 0\% }\end{array}$ & $\begin{array}{c}\text { Tepung Cacing } \\
\text { Tanah 5\% }\end{array}$ & $\begin{array}{c}\text { Tepung Cacing } \\
\text { Tanah 10\% }\end{array}$ & $\begin{array}{c}\text { Tepung Cacing } \\
\text { Tanah 15\% }\end{array}$ \\
\hline Bahan Baku Pakan $^{\text {Tepung Pelet Komersial }}{ }^{1)}$ & 84,5 & 84,5 & 84,5 & 84,5 \\
Tepung Cacing Tanah $^{2)}$ & 0 & 5 & 10 & 15 \\
Tepung Terigu $^{1)}$ & 15 & 10 & 5 & 0 \\
CMC $^{1)}$ & 0,5 & 0,5 & 0,5 & 0,5 \\
Komposisi Proksimat $_{\text {Protein }(\%)^{3)}}$ & 29,73 & 33,01 & 35,14 & 37,40 \\
BETN $(\%)^{3)}$ & 34,94 & 33,84 & 33,48 & 29,01 \\
Lemak $(\%)^{3)}$ & 9,31 & 10,53 & 11,84 & 12,47 \\
En $(k k a l)$ & 266,86 & 285,43 & 302,56 & 304,43 \\
Rasio E/P & 8,97 & 8,65 & 8,61 & 8,14 \\
\hline
\end{tabular}

Keterangan:

${ }^{1)}$ Bahan diperoleh dari toko komersil di Semarang.

${ }^{2}$ Bahan diperoleh dari rumah produksi di Rembang.

${ }^{3)}$ Hasil analisis proksimat (Laboratorium Nutrisi Pakan, FPP, UNDIP, Semarang).

\section{Pengumpulan dan Analisis Data}

Tingkat Konsumsi Pakan

Menurut Setiawati et al. (2008), tingkat konsumsi pakan dihitung dengan cara menimbang jumlah pakan yang dikonsumsi ikan setiap harinya selama masa pemeliharaan.

$\mathrm{TKP}=\mathrm{F} 1-\mathrm{F} 2$

keterangan:

$\begin{array}{ll}\text { TKP } & \text { : Tingkat konsumsi pakan } \\ \text { F1 } & \text { : Jumlah pakan awal }(\mathrm{g}) \\ \text { F2 } & \text { : Jumlah pakan sisa }(\mathrm{g})\end{array}$

Efisiensi Pemanfaatan Pakan

Efisiensi pakan dapat dihitung dengan menggunakan rumus Zonneveld et al. (1991).

$$
\mathrm{EPP}=\frac{\mathrm{W}_{\mathrm{t}}-\mathrm{W}_{0}}{\mathrm{~F}} \times 100 \%
$$

keterangan:
EPP
: Efisiensi pemanfaatan pakan $(\%)$
$\mathrm{W}_{\mathrm{t}} \quad$ : Biomassa ikan uji pada akhir pengamatan $(\mathrm{g})$
$\mathrm{W}_{0} \quad$ : Biomassa ikan uji pada awal pengamatan $(\mathrm{g})$
$\mathrm{F} \quad$ : Jumlah pakan ikan yang diberikan selama pengamatan (g)

$\underline{\text { Protein Efisiensi Rasio }}$

Perhitungan nilai protein efisiensi rasio dengan menggunakan rumus Zonneveld et al. (1991).

$$
\mathrm{PER}=\frac{\mathrm{W}_{\mathrm{t}}-\mathrm{W}_{\mathrm{o}}}{\mathrm{Pi}} \times 100 \%
$$

keterangan:

$$
\begin{array}{ll}
\text { PER } & \text { : Protein efisiensi rasio }(\%) \\
\mathrm{W}_{\mathrm{t}} & \text { : Bobot total ikan pada akhir penelitian }(\mathrm{g}) \\
\mathrm{W}_{\mathrm{o}} & \text { : Bobot total ikan pada awal penelitian }(\mathrm{g}) \\
\mathrm{Pi} & \text { : Berat pakan yang dikonsumsi } \mathrm{x} \% \text { protein pakan }
\end{array}
$$

$\underline{\text { Pertumbuhan Bobot Mutlak }}$

Nilai pertumbuhan bobot mutlak dapat dihitung dengan rumus Zonneveld et al. (1991).

$$
\mathrm{G}=\Delta \mathrm{W}=\mathrm{W}_{\mathrm{t}}-\mathrm{W}_{0}
$$

keterangan:

$$
\begin{array}{ll}
\mathrm{G} & : \text { Pertumbuhan bobot mutlak }(\mathrm{g}) \\
\mathrm{W}_{\mathrm{t}} & : \text { Bobot ikan pada waktu } \mathrm{t}(\mathrm{g}) \\
\mathrm{W}_{\mathrm{o}} & : \text { Bobot ikan awal }(\mathrm{g})
\end{array}
$$


Laju Pertumbuhan Spesifik

Spcific Growth Rate (SGR) ikan dihitung dengan menggunakan rumus Zonneveld et al. (1991).

$$
\mathrm{SGR}=\frac{\left(\ln \mathrm{W}_{\mathrm{t}}-\ln \mathrm{W}_{0}\right)}{\mathrm{t}} \times 100 \%
$$

keterangan:

$$
\begin{array}{ll}
\mathrm{SGR} & \text { : Laju pertumbuhan spesifik (\% BW/hari) } \\
\mathrm{W}_{\mathrm{t}} & \text { : bobot ikan pada saat akhir }(\mathrm{g}) \\
\mathrm{W}_{0} & \text { : bobot ikan pada saat awal }(\mathrm{g}) \\
\mathrm{T} & \text { : waktu pengamatan (hari) }
\end{array}
$$

\section{$\frac{\text { Kelulushidupan }}{\text { Survival }}$}

Survival Rate dapat dihitung dengan rumus Zonneveld et al. (1991).

$$
\mathrm{SR}=\frac{\mathrm{N}_{\mathrm{t}}}{\mathrm{N}_{0}} \times 100 \%
$$

keterangan:

SR : Tingkat kelulushidupan ikan (\%)

$\mathrm{N}_{\mathrm{t}} \quad$ : Jumlah ikan pada akhir penelitian (ekor)

$\mathrm{N}_{0} \quad$ : Jumlah ikan padaawal penelitian (ekor)

\section{Uji Kesukaan Makan}

Akuarium yang digunakan disekat menggunakan papan menjadi 3 bagian, namun bagian yang tengah lebih besar dari kedua bagian yang disamping. Pengujian dilakukan dengan menggunakan enam buah akuarium dengan perlakuan dua dosis pakan berbeda tiap akuarium. Ikan yang digunakan sebanyak 10 ekor diletakkan pada bagian tengah akuarium yang disekat. Pengamatan satu akuarium sebanyak 30 ulangan, setiap satu menit diamati dan dihitung ikan yang mendekati pakan. Hasil diperoleh dari rata-rata ikan mendekati pakan selama pengamatan yang dinyatakan dalam persen.

\section{Kualitas Air}

Pengamatan kualitas air meliputi suhu, oksigen terlarut (DO), kandungan ammonia $\left(\mathrm{NH}_{3}\right)$ dan tingkat keasaman $(\mathrm{pH})$. Pengamatan kualitas air yang terdiri dari kandungan ammonia dan $\mathrm{pH}$ dilakukan pada awal dan akhir penelitian, sedangkan pengamatan kualitas air seperti DO dan suhu dilakukan setiap hari. Pengukuran kandungan ammonia dianalisis menggunakan spectrophotometer, dan pengukuran $\mathrm{pH}$ dilakukan dengan menggunakan $\mathrm{pH}$ meter dengan cara mencelupkan ujung alat indikator (probe) ke dalam air kemudian menunggu hingga konstan dan mencatat nilainya. Pengukuran oksigen terlarut dan suhu menggunakan DO meter dengan mencelupkan ujung alat indikator (probe) ke dalam air kemudian menunggu hingga konstan dan mencatat nilainya.

\section{Evaluasi Data}

Data yang diperoleh meliputi TKP, EPP, PER, G, SGR, dan SR, terlebih dahulu dilakukan uji normalitas, uji homogenitas, dan uji additivitas guna memastikan bahwa data bersifat normal, homogen, dan aditif. Data kemudian dilakukan uji lebih lanjut yaitu analisis ragam (ANOVA). Analisis data dilakukan dengan menggunakan Microsoft Excel dan SPSS. Data dianalisis ragam (uji F) pada taraf kepercayaan 95\%. Apabila dalam analisis ragam diperoleh beda nyata $(\mathrm{P}<0,05)$, maka dilakukan uji wilayah ganda Duncan untuk mengetahui perbedaan nilai tengah antara perlakuan (Srigandono, 1992). Data kualitas air dianalisis secara deskriptif dan dibandingkan dengan nilai kelayakan kualitas air pada budidaya ikan patin.

\section{HASIL}

Hasil penelitian menunjukkan bahwa penambahan tepung cacing tanah sebagai atraktan dalam pakan memiliki pengaruh yang nyata $(\mathrm{P}<0.05)$ terhadap tingkat konsumsi pakan $(\mathrm{TKP})$, efisiensi pemanfaatan pakan (EPP), protein efisisensi rasio (PER), Pertumbuhan Bobot Mutlak (G) dan laju pertumbuhan spesifik (SGR) ikan patin (Pangasius $\mathrm{sp}$.), serta tidak memiliki pengaruh yang nyata $(\mathrm{P}>0.05)$ terhadap nilai kelulushidupan (SR) ikan patin (Pangasius sp.). Hasil penelitian nilai TKP, EPP, PER, G, SGR dan SR ikan patin (Pangasius sp.) yang dipelihara selama 42 hari dapat dilihat pada Tabel 2. 
Tabel 2. Nilai Rerata TKP, EPP, PER, G, SGR dan SR pada Ikan Patin (Pangasius sp.) yang Dipelihara selama 42 Hari

\begin{tabular}{lcccc}
\hline \multirow{2}{*}{$\begin{array}{c}\text { Variabel yang } \\
\text { diamati }\end{array}$} & \multicolumn{4}{c}{ Perlakuan (\% Tepung Cacing Tanah dalam Pakan) } \\
\cline { 2 - 5 } TKP (g) & 0 & 5 & 10 & 15 \\
EPP (\%) & $140,03 \pm 0,76^{\mathrm{c}}$ & $145,70 \pm 1,30^{\mathrm{b}}$ & $159,73 \pm 0,42^{\mathrm{a}}$ & $158,73 \pm 0,54^{\mathrm{a}}$ \\
PER (\%) & $45,92 \pm 12,03^{\mathrm{c}}$ & $62,61 \pm 5,95^{\mathrm{b}}$ & $81,06 \pm 4,79^{\mathrm{a}}$ & $71,39 \pm 5,60^{\mathrm{ab}}$ \\
G (g) & $1,54 \pm 0,41^{\mathrm{b}}$ & $1,89 \pm 0,18^{\mathrm{ab}}$ & $2,31 \pm 0,14^{\mathrm{a}}$ & $1,91 \pm 0,15^{\mathrm{ab}}$ \\
SGR (\%/hari) & $6,34 \pm 0,24^{\mathrm{b}}$ & $8,53 \pm 1,18^{\mathrm{a}}$ & $9,76 \pm 0,73^{\mathrm{a}}$ & $9,43 \pm 1,17^{\mathrm{a}}$ \\
SR $(\%)$ & $1,20 \pm 0,27^{\mathrm{c}}$ & $1,53 \pm 0,10^{\mathrm{b}}$ & $1,97 \pm 0,07^{\mathrm{a}}$ & $1,79 \pm 0,09^{\mathrm{ab}}$ \\
\hline
\end{tabular}

Keterangan: Nilai dengan superscript yang berbeda menunjukkan perbedaan yang nyata $(\mathrm{P}<0.05)$.

Berdasarkan data nilai TKP, EPP, PER, G, SGR dan SR pada ikan patin (Pangasius sp.) yang dipelihara selama 42 hari dapat dilihat pada Gambar 1.

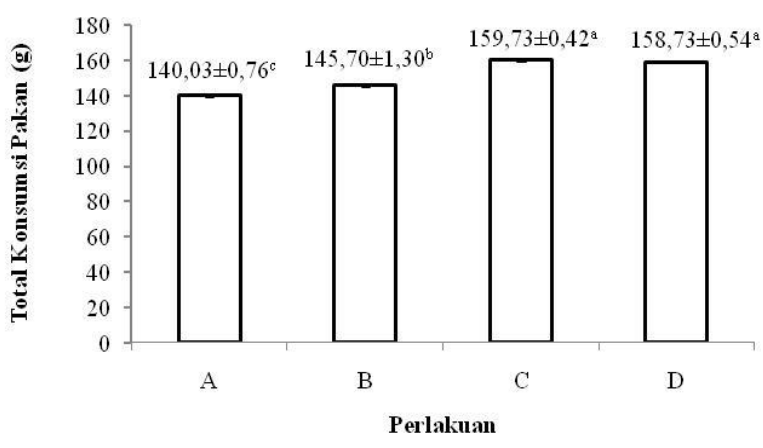

(A)

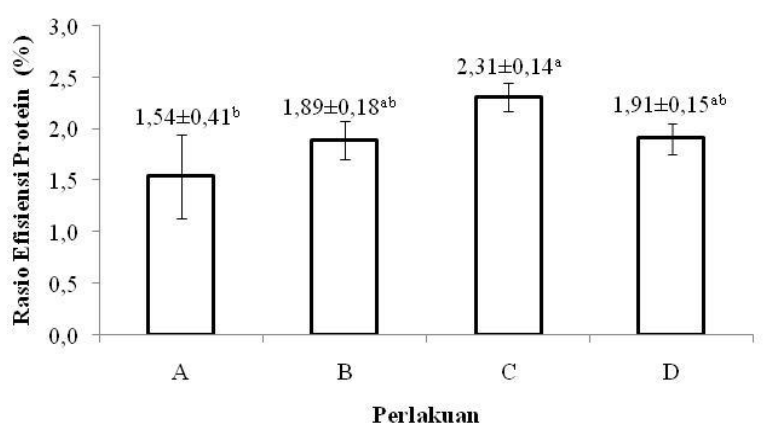

(C)

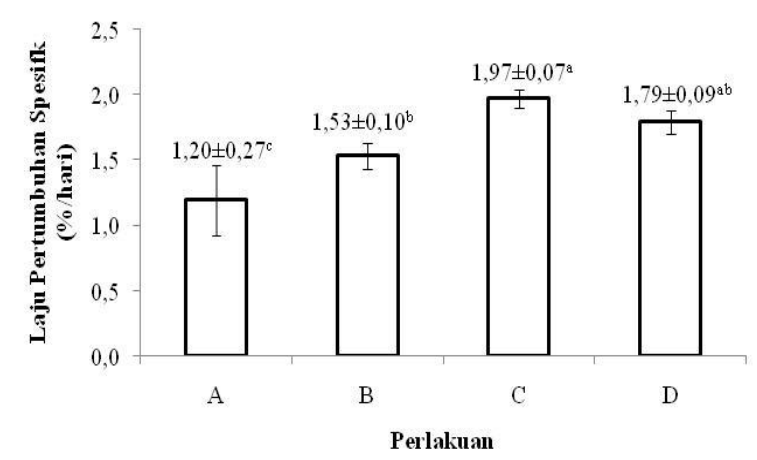

(E)

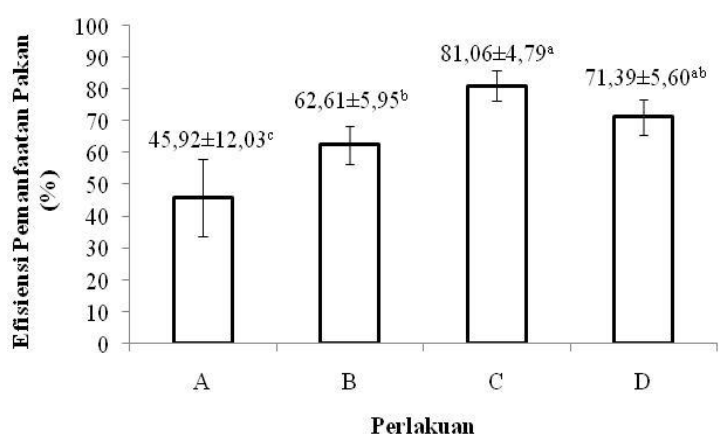

(B)

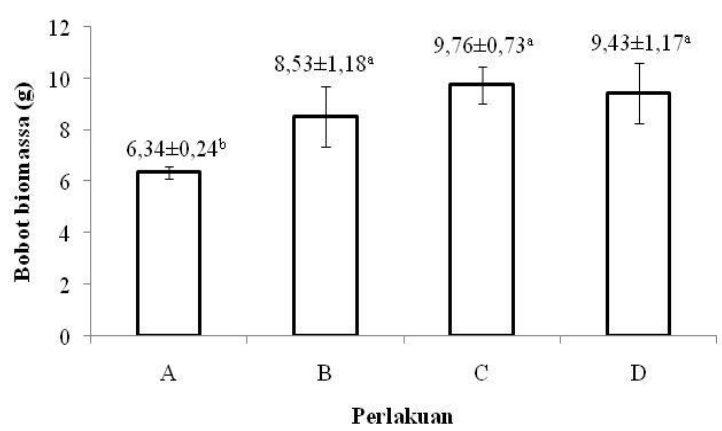

(D)

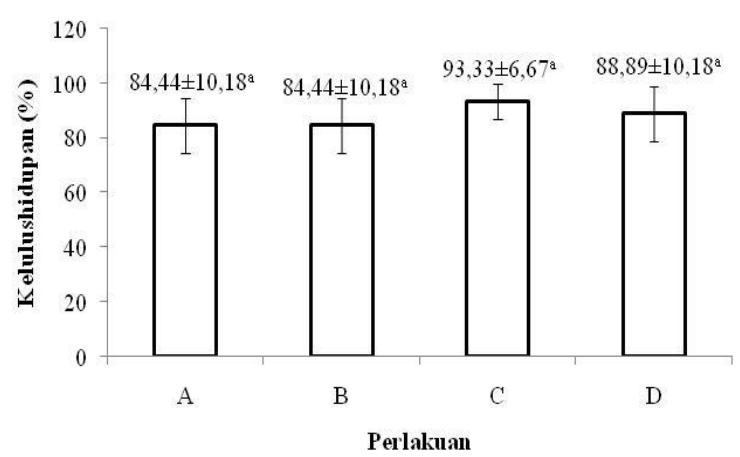

(F)

Gambar 1. Nilai Total Konsumsi Pakan (A), Efisiensi Pemanfaatan Pakan (B), Rasio Efisiensi protein (C), Bobot Biomassa (D), Laju Pertumbuhan Spesifik (E) dan Kelulushidupan (F) pada Ikan Patin (Pangasius sp.) yang Dipelihara selama 42 Hari. 
Hasil dari uji kesukaan makan pada dosis $10 \%$ tepung cacing tanah disukai oleh ikan patin dengan persentase $44 \%$ ikan yang mendekati pakan. Perlakuan dosis $15 \%$ tepung cacing tanah dengan persentase $41 \%$, dosis 5\% tepung cacing tanah dengan persentase $31 \%$ dan dosis $0 \%$ tepung cacing tanah dengan persentase $23 \%$.

Hasil pengukuran parameter kualitas air pada media pemeliharaan Ikan patin (Pangasius sp.) selama pemeliharaan tersaji pada Tabel 3.

Tabel 3. Hasil Pengukuran Kualitas Air Media Pemeliharaan Ikan Patin (Pangasius sp.) yang Dipelihara selama 42 Hari

\begin{tabular}{|c|c|c|c|c|}
\hline \multirow{2}{*}{$\begin{array}{l}\text { Perlakuan (\% } \\
\text { Tepung Cacing } \\
\text { Tanah dalam } \\
\text { Pakan) }\end{array}$} & \multicolumn{4}{|c|}{ Kisaran Nilai Parameter Kualitas Air } \\
\hline & Suhu $\left({ }^{0} \mathrm{C}\right)$ & $\mathrm{pH}$ & $\mathrm{DO}(\mathrm{mg} / \mathrm{L})$ & $\mathrm{NH}_{3}(\mathrm{mg} / \mathrm{L})$ \\
\hline 0 & $27,90-29,60$ & 7,00 & $5,38-5,52$ & $0,0036-0,0094$ \\
\hline 5 & $27,70-30,90$ & 7,00 & $5,39-5,50$ & $0,0047-0,0073$ \\
\hline 10 & $27,80-30,90$ & 7,00 & $5,37-5,52$ & $0,0051-0,0076$ \\
\hline 15 & $27,80-30,90$ & 7,00 & $5,39-5,52$ & $0,0061-0,0095$ \\
\hline Kelayakan & $27,00-32,00^{\mathrm{a}}$ & $6,50-8,50^{\mathrm{a}}$ & $\geq 3,00^{\mathrm{a}}$ & $<0,01^{\mathrm{b}}$ \\
\hline
\end{tabular}

Keterangan: ${ }^{a}$ SNI (2009), ${ }^{b} W W F(2015)$.

Hasil pengukuran parameter kualitas air selama penelitian menunjukkan bahwa nilai parameter kualitas air selama penelitian tersebut masih berada dalam kondisi layak untuk dijadikan media budidaya ikan patin (Pangasius sp.). Hal ini didasarkan dari pustaka tentang kondisi kualitas air yang optimal untuk ikan patin (Pangasius sp.).

\section{PEMBAHASAN}

\section{Efisiensi pemanfaatan pakan}

Hasil analisa ragam menunjukkan bahwa tepung cacing tanah sebagai atraktan dalam pakan berpengaruh nyata $(\mathrm{P}<0,05)$ terhadap nilai total konsumsi pakan ikan patin (Pangasius sp.). Selain itu, konsumsi pakan juga dapat disebabkan karena adanya kandungan tepung cacing tanah dalam pakan. Menurut Julendra et al. (2010), cacing tanah (Lumbricus sp.) dapat berperan sebagai aditif pemacu pertumbuhan (growth promoters) yang dapat memaksimalkan absorbsi nutrien dalam saluran cerna, sehingga memacu pertumbuhan dan mengefisienkan konsumsi pakan.

Penambahan tepung cacing tanah sebagai atraktan dalam pakan berpengaruh nyata terhadap total konsumsi pakan ikan patin. Penambahan tepung cacing tanah dalam pakan tertinggi diperoleh oleh pakan dengan dosis $10 \%$

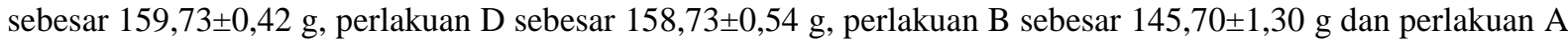
sebesar 140,03 $\pm 0,76 \mathrm{~g}$. Evans et al. (2014) berpendapat bahwa semakin tinggi kadar atraktan cacing dalam pakan yang diberikan, maka semakin meningkat pula jumlah konsumsi pakan harian ikan gabus. Jumlah pakan yang mampu dikonsumsi ikan setiap harinya merupakan salah satu faktor yang mempengaruhi potensi ikan untuk tumbuh. Laju konsumsi pakan harian berhubungan erat dengan pengosongan perut.Penurunan jumlah konsumsi pakan diduga dipengaruhi oleh palatabilitas pakan yang semakin berkurang. Suprayudi et al. (2014), palatabilitas atau respon terhadap pakan dipengaruhi oleh kondisi performa pakan yang meliputi sifat fisik berupa bentuk, warna, tekstur, dan ukuran, maupun kimiawi yang membentuk rasa dan aroma.

Hasil efisiensi pemanfaatan pakan ikan patin selama pemeliharaan pada masing-masing perlakuan dari yang tertinggi hingga terendah adalah perlakuan C sebesar $81,06 \pm 4,79 \%$, perlakuan D sebesar 71,39 $\pm 5,60 \%$, perlakuan B sebesar $62,61 \pm 5,95 \%$ dan perlakuan A sebesar 45,92 $\pm 12,03 \%$. Salah satu faktor yang mempengaruhi nilai efisiensi pakan tinggi karena adanya kandungan tepung cacing tanah dalam pakan. Selain itu, kualitas dan kandungan nutrisi pakan yang mengandung tepung cacing tanah dapat mempengaruhi pertumbuhan ikan patin. Penelitian yang sama dilakukan oleh Evans et al. (2014) dengan hasil terbaik dari efisiensi pemanfaatan pakan pada dosis $10 \%$ sebesar 22,46\% untuk ikan gabus. Cholis et al. (2016), pemberian tepung cacing tanah sebagai pakan terbukti mempercepat pertumbuhan berat hidup, meningkatkan pembentukan jaringan otot, dan meningkatkan efisiensi pakan.

Efisiensi pakan yang baik dapat meningkatkan pertumbuhan pada ikan. Kualitas dan nutrisi pakan berpengaruh pada efisiensi pakan, apabila efisiensi pakan mendapatkan hasil yang baik maka dapat meningkatkan laju pertumbuhan ikan. Menurut Handayani (2006), tingkat efisiensi penggunaan pakan pada ikan ditentukan oleh pertumbuhan dan jumlah pakan yang diberikan. Keefisienan penggunaan pakan menunjukkan nilai pakan yang dapat merubah menjadi pertambahan pada berat badan ikan. Tingkat efisiensi penggunaan pakan yang terbaik diperoleh pada perlakuan dengan kualitas pakan yang baik, kualitas pakan yang baik mengakibatkan energi yang diperoleh lebih banyak untuk pertumbuhan sehingga dengan pemberian pakan yang sedikit diharapkan laju pertumbuhan meningkat.

Perlakuan terbaik yang didapatkan dari rasio efisiensi protein pada perlakuan dosis tepung cacing tanah $10 \%$. Perlakuan dosis tepung cacing tanah $15 \%$ mengalami penurunan dengan nilai $1,91 \pm 0,15 \%$ yang memiliki 
protein sebesar $37,40 \%$. Penurunan nilai tersebut diduga karena protein yang ada dalam pakan dosis $15 \%$ melampaui dosis optimal protein yang baik untuk ikan patin. Menurut Aslamyah dan Karim (2013), penggunaan protein maksimum untuk pertumbuhan dan kebutuhan energi dipenuhi sumber lain, merupakan suatu proses yang dikenal dengan istilah protein sparing effect. Pakan dengan rasio protein per energi optimum akan menghasilkan pertumbuhan dan pemanfaatan pakan yang paling optimal. Peningkatan kadar protein pakan berakibat pada peningkatan pertumbuhan sampai batas tertentu pada kadar energi yang sama. Selanjutnya dijelaskan bahwa pakan yang kandungan energinya kurang menyebabkan terjadinya penggunaan sebagian besar protein sebagai sumber energi. Sebaliknya jika kandungan energi pakan terlalu tinggi dapat menyebabkan pakan yang dimakan berkurang dan penerimaan nutrien lain termasuk protein yang diperlukan untuk pertumbuhan juga berkurang.

\section{Pertumbuhan}

Pertambahan bobot mutlak ikan patin selama pemeliharaan pada masing-masing perlakuan dari yang tertinggi hingga terendah adalah perlakuan C sebesar 9,76 $\pm 0,73 \mathrm{~g}$, perlakuan D sebesar 9,43 $\pm 1,17 \mathrm{~g}$, perlakuan B

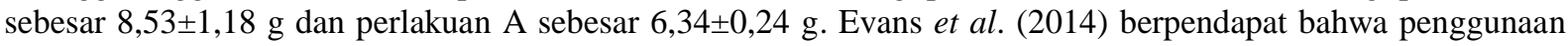
tepung cacing tanah sebagai atraktan dalam pakan pada ikan gabus (Ophiocephalus striatus) memberikan pertumbuhan yang baik pada dosis terbaik yaitu 10\%. Menurut Aslamyah dan Karim (2013), penambahan tepung cacing tanah dalam pakan ikan bandeng terbaik pada dosis $26 \%$ yang di substitusi dengan tepung ikan. Menurut Boaru et al. (2016), penggunaan tepung cacing tanah juga digunakan sebagai suplemen ikan pedang (Xiphophorus hellerii) dan memberikan dosis yang optimal $10 \%$.

Hasil analisa ragam menunjukkan bahwa tepung cacing tanah sebagai atraktan dalam pakan berpengaruh nyata $(\mathrm{P}<0,05)$ terhadap nilai pertambahan bobot mutlak ikan patin (Pangasius sp.). Pertumbuhan ikan patin yang baik diduga karena kandungan protein yang ada didalam pakan sesuai dengan kebutuhan protein tubuh ikan patin. Kandungan protein yang cukup bagi ikan digunakan ikan sebagai pertumbuhan. Menurut Wardhani et al. (2011), kebutuhan protein patin pada stadia benih adalah 30-36\%. Kebutuhan lemak patin untuk stadia benih adalah 1218\%. Nilai karbohidrat yang jauh tinggi dibandingkan kebutuhan normalnya yaitu 30-35\%. Kandungan karbohidrat pakan yang melebihi kebutuhan ikan dapat menyebabkan terhambatnya pertumbuhan, karena semakin tinggi kandungan karbohidrat maka jumlah kandungan nutrisi penting lainnya seperti protein akan menurun.

Pemberian pakan dengan penambahan tepung cacing tanah sebagai atraktan memberikan efek yang lebih baik terhadap pertumbuhan ikan patin. Berdasarkan hasil pengamatan penambahan $10 \%$ tepung cacing tanah

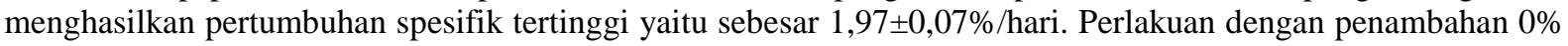
tepung cacing tanah menghasilkan laju pertumbuhan lebih rendah dibandingkan perlakuan dengan penambahan $10 \%$ tepung cacing tanah. Hal ini diduga pada perlakuan $10 \%$ menghasilkan pertumbuhan yang optimal. Menurut Evans et al. (2014), penambahan tepung cacing tanah sebagai atraktan dalam pakan untuk ikan gabus menghasilkan laju pertumbuhan spesifik sebesar 5,49\%/hari dengan dosis $10 \%$. Penelitian lain dilakukan oleh Boaru et al. (2016) bahwa nilai laju pertumbuhan spesifik pada ikan pedang (X. helleri) dengan penambahan tepung cacing tanah sebagai suplemen sebesar 0,356\%/hari dengan dosis 10\%. Menurut Setiawati et al. (2013), ikan akan tumbuh apabila nutrisi pakan yang dicerna dan diserap oleh tubuh ikan lebih besar dari jumlah yang diperlukan untuk memelihara tubuhnya. Laju pertumbuhan dan laju pertumbuhan spesifik berkaitan erat dengan pertambahan berat tubuh yang berasal dari pakan yang dikonsumsi.

Pakan merupakan faktor terpenting dalam budidaya perikanan. Pemberian pakan yang baik juga dapat mempengaruhi laju pertumbuhan spesifik ikan patin. Pakan yang berkualitas memiliki kandungan nutrisi yang lebih baik dalam petumbuhan. Menurut Khasani (2013), salah satu faktor utama yang mempengaruhi laju pertumbuhan dan kesehatan ikan adalah pakan, baik aspek kandungan nutrisi maupun kuantitas. Pakan buatan berkualitas memiliki tingkat palatabilitas yang tinggi. Ikan cepat merespon pakan yang memiliki senyawa yang merangsang indera penciumannya karena adanya mekanisme kemoreseptor. Senyawa tersebut dikenal sebagai atraktan. Berbagai senyawa yang memiliki sifat atraktan baik yang bersifat alami maupun sintetis telah digunakan pada pakan buatan.Menurut Isnawati et al. (2015) berpendapat bahwa laju pertumbuhan yang tinggi berkaitan dengan efisiensi pakan yang tinggi juga. Efisiensi pakan yang tinggi menunjukkan penggunaan pakan yang efisien, sehingga hanya sedikit zat makanan yang dirombak untuk memenuhi kebutuhan energi dan selebihnya digunakan untuk pertumbuhan. Efisiensi pakan merupakan rasio antara pertambahan bobot dengan jumlah pakan yang diberikan selama penelitian.

\section{Kelulushidupan}

Hasil analisa ragam menunjukkan bahwa tepung cacing tanah sebagai atraktan dalam pakan tidak berpengaruh nyata $(\mathrm{P}>0,05)$ terhadap nilai kelulushidupan ikan patin (Pangasius sp.). Kelulushidupan ikan patin selama pemeliharaan pada masing-masing perlakuan dari yang tertinggi hingga terendah adalah perlakuan $\mathrm{C}$

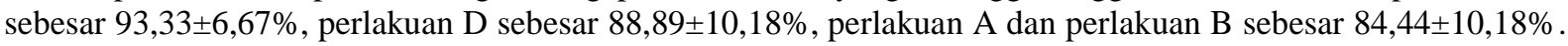
Perlakuan $\mathrm{C}$ menghasilkan tingkat konsumsi pakan tertinggi dibandingkan dengan perlakuan A, perlakuan B dan perlakuan D. Menurut Leo et al. (2014), kecepatan pertumbuhan tergantung pada jumlah pakan yang dikonsumsikan, kualitas air dan faktor lain seperti keturunan, daya tahan serta kemampuan ikan tersebut memanfaatkan pakan. Minggawati dan Saptono (2012) berpendapat bahwa kualitas suatu perairan memberikan 
pengaruh yang cukup besar terhadap survival dan pertumbuhan makhluk hidup di perairan itu sendiri. Lingkungan yang baik, hiegienis bagi hewan diperlukan untuk pertumbuhan dan kelangsungan hidupnya.

\section{Uji kesukaan makan}

Berdasarkan hasil dari uji kesukaan makan diperoleh bahwa penambahan tepung cacing tanah sebagai atraktan ikan patin perlakuan $\mathrm{C}$ dosis $10 \%$ memberikan respon yang baik pada ikan. Pertumbuhan ikan patin pada perlakuan $\mathrm{C}$ juga memberikan nilai tertinggi dari perlakuan yang lain. Pakan dengan dosis $10 \%$ dan $15 \%$ paling disukai oleh ikan patin, diduga karena kandungan asam amino yang memberikan daya tarik untuk ikan. Suprayudi et al. (2014), hal inilah yang kemudian menumbuhkan daya tarik dan merangsang ikan untuk mengkonsumsi suatu pakan yang diberikan. palatabilitas pakan berkorelasi dengan keberadaan asam amino bebas seperti betain, asam glutamat, alanin, dan glisin.

Tepung cacing tanah yang ditambahkan dalam pakan ikan patin disukai oleh ikan. Diduga karena kandungan dari cacing tanah tinggi protein dan asam amino, sehingga disukai oleh ikan patin sebagai atraktan. A'yunin dan Pratiwi (2016) berpendapat bahwa kandungan gizi Lumbricus rubellus yaitu protein 60-70\%, lemak kasar $7 \%$, kalsium $0,55 \%$, fosfor $1 \%$, serat kasar 1,08\%. Selain mengandung protein yang tinggi cacing tanah juga mengandung energi 900-1.400 kal dan abu 8-10\%. Menurut Evans et al. (2014), cacing tanah mengandung asam amino bebas yang cukup lengkap, diantaranya yang merupakan jenis asamamino yang berupa zat atraktif adalah seperti glisin, valin, dan lain sebagainya. Beberapa jenis asam amino seperti glisin, proline, dan valin memberikan respon makan yang lebih sensitif.

\section{Kualitas air}

Kualitas air merupakan data pendukung dari kegiatan budidaya, hasil pengukuran terhadap beberapa parameter kualitas air diantaranya suhu, pH, oksigen terlarut dan amonia. Berdasarkan data kualitas air pada pemeliharaan ikan patin yang telah diamati selama 42 hari, didapatkan hasil suhu $27,7-30,9^{\circ} \mathrm{C}$. Suhu yang diperoleh selama penelitian sudah menunjukkan suhu yang optimal dalam pemeliharaan ikan patin. Data oksigen terlarut pada pemelihraan ikan patin berkisar antara 5,37-5,52 mg/L. Nilai pH yang didapatkan sebesar 7. Menurut SNI (2009), pengelolaan kualitas air yang digunakan selama proses produksi diupayakan untuk memenuhi persyaratan sebagai berikut, suhu $27-32^{\circ} \mathrm{C}$, nilai $\mathrm{pH} 6,5-8,5, \mathrm{DO} \geq 3 \mathrm{mg} / \mathrm{L}$. WWF (2015) berpendapat bahwa kualitas air yang baik digunakan selama budidaya ikan patin antara lain suhu $27-32^{\circ} \mathrm{C}$, nilai pH $6,5-8,5, \mathrm{DO} \geq$ $3 \mathrm{mg} / \mathrm{L}$, ammonia $\left(\mathrm{NH}_{3}\right)<0,01 \mathrm{mg} / \mathrm{L}$, nitrit $\left(\mathrm{NO}_{2}\right)<1 \mathrm{mg} / \mathrm{L}$ dan kecerahan lebih dari $25 \mathrm{~cm}$.

\section{Kesimpulan dan Saran}

Penelitian ini dapat disimpulkan bahwa pemberian tepung cacing tanah (Lumbricus sp.) sebagai atraktan dalam pakan berpengaruh nyata $(\mathrm{P}<0.05)$ terhadap tingkat konsumsi pakan, efisiensi pakan dan pertumbuhan ikan patin, namun tidak berpengaruh nyata $(\mathrm{P}>0.05)$ terhadap kelulushidupan ikan patin. Uji kesukaan makan ikan patin terhadap atraktan tepung cacing tanah menunjukkan hasil tertinggi pada perlakuan $\mathrm{C}$ dosis $10 \%$ dengan persentase 44\% ikan patin yang mendekati pakan. Dosis terbaik tepung cacing tanah (Lumbricus sp.) sebagai atraktan dalam pakan terhadap tingkat konsumsi pakan, efisiensi pakan dan pertumbuhan ikan patin (Pangasius sp.) adalah perlakuan C $(10 \%)$.

Saran yang dapat diberikan pada penelitian ini adalah sebaiknya penambahan tepung cacing tanah (Lumbricus sp.) sebagai atraktan dapat diterapkan dengan konsentrasi $10 \%$ pada pakan buatan dan dapat diterapkan pada ikan patin dengan ukuran yang berbeda dan kultivan lain agar mendapatkan hasil tingkat konsumsi pakan, efisiensi pakan dan pertumbuhan yang lebih baik.

\section{UCAPAN TERIMA KASIH}

Terima kasih penulis ucapkan kepada Bapak Taufik selaku Kepala Balai Benih Ikan Siwarak, Semarang atas fasilitas sarana dan prasarana yang diberikan dalam penelitian dan semua pihak yang telah membantu mulai dari persiapan hingga jalannya penelitian. 


\section{DAFTAR PUSTAKA}

Aslamyah, S. dan M.Y. Karim. 2013. Potensi Tepung Cacing Tanah Lumbricus sp. Sebagai Pengganti Tepung Ikan dalam Pakan Terhadap Kinerja Pertumbuhan, Komposisi Tubuh, Kadar Glikogen Hati dan Otot Ikan Bandeng Chanos chanos Forsskal. Jurnal Iktiologi Indonesia, 13(1): 67-76.

A'yunin, Q. dan D.C. Pratiwi. 2016. Pemanfaatan Limbah Organik Sebagai Pembaruan Teknologi Media Budidaya Cacing Tanah. Journal of Innovation and Applied Technology, 2 (1): 226-229.

Beauty, G., A. Yustiati dan R. Grandiosa. 2012. Pengaruh Dosis Mikroorganisme Probiotik pada Media Pemeliharaan Terhadap Kelangsungan Hidup dan Pertumbuhan Benih Mas Koki (Carassius auratus) dengan Padat Penebaran Berbeda. Jurnal Perikanan dan Kelautan, 3(9): 1-6.

Boaru, A., D. Struti, S.V. Daraban and B. Georgescu. 2016. The Effect of Earthworm Meal (Eisenia foetida) as Protein Supplement for the Growth of Xiphophorus helleri Juveniles. Poeciliid Research, 6(1):4-9.

Cholis, N., E. Setyowati dan I.W. Nursita. 2016. Pengaruh Penambahan Kultur Azotobacter pada Feses Kambing terhadap Kualitas Media dan Produktivitas Cacing Tanah (Lumbricus rubellus). Jurnal Ilmu-Ilmu Peternakan, 26 (2): 30-41.

Evans, W., H. Yanto dan Sunarto. 2014. Laju Konsumsi Pakan dan Kinerja Pertumbuhan Benih Ikan Gabus (Ophiocephalus striatus) dengan Pemberian Atraktan Cacing Koot (Pheretima sp.). Jurnal Ruaya, 1(1): 1-8.

Handayani, H. 2006. Pemanfaatan Tepung Azolla sebagai Penyusun Pakan Ikan terhadap Pertumbuhan dan Daya Cerna Ikan Nila Gift (Oreochromis sp). GAMMA, 2(1): 162-170.

Isnawati, N., R. Sidik dan G. Mahasri. 2015. Potensi Daun Pepaya untuk Meningkatkan Efisiensi Pemanfaatan Pakan, Rasio Efisiensi Protein dan Laju Pertumbuhan Relatif pada Budidaya Ikan Nila (Oreochromis niloticus). Jurnal Ilmiah Perikanan dan Kelautan, 7(2): 121-124.

Julendra H., Zuprizal dan Supadmo. 2010. Penggunaan Tepung Cacing Tanah (Lumbricus rubellus) Sebagai Aditif Pakan Terhadap Penampilan Produksi Ayam Pedaging, Profil Darah, dan Kecernaan Protein. Buletin Peternakan, 34(1): 21-29.

Khasani, I. 2013. Atraktan pada Pakan Ikan: Jenis, Fungsi, dan Respons Ikan.Media Akuakultur, 8(2): 127-133.

Leo, B., E. I. Raharjo dan Farida. 2014. Kombinasi Pellet dan Cacing Tanah (Lumbricus rubellus) Terhadap Pertumbuhan dan Kelangsungan Hidup Ikan Ringau (Datnioides mescrolepis). Fakultas Perikanan dan Ilmu Kelautan, Universitas Muhammadiyah Pontianak: 1-8.

Minggawati, I. dan Saptono. 2012. Parameter Kualitas Air untuk Budidaya Ikan Patin (Pangasius pangasius) di Karamba Sungai Kahayan, Kota Palangka Raya. Jurnal Ilmu Hewani Tropika, 1(1): 27-30.

Rachmawati, D. dan I. Samidjan. 2013. Efektivitas Substitusi Tepung Ikan dengan Tepung Maggot dalam Pakan Buatan Terhadap Pertumbuhan dan Kelulushidupan Ikan Patin (Pangasius pangasius). Jurnal Saintek Perikanan, 9(1): 62-67.

Setiawati, M., R. Sutajaya dan M.A. Suprayudi. 2008. Pengaruh Perbedaan Kadar Protein dan Rasio Energi Protein Pakan terhadap Kinerja Pertumbuhan Fingerling Ikan Mas (Cyprinus carpio). Jurnal Akuakultur Indonesia, 7(2): 171-178.

Setiawati, J.E., Tarsim, Y.T. Adipura dan S. Hudaidah. 2013. Pengaruh Penambahan Probiotik pada Pakan dengan Dosis Berbeda Terhadap Pertumbuhan, Kelulushidupan, Efisiensi Pakan dan Retensi Protein Ikan Patin (Pangasius hypophthalmus). Jurnal Rekayasa dan Teknologi Budidaya Perairan, 1(2): 151-162.

SNI 7471.5. 2009. Ikan Patin Jambal (Pangasius djambal) Bagian 5 : Produksi Kelas Pembesaran di Kolam, 10 hlm.

Srigandono, B. 1992. Rancangan Percobaan. Fakultas Peternakan, Universitas Diponegoro, Semarang : 178 hlm.

Suprayudi, M. A., W.S. Irawan dan N.B.P. Utomo. 2014. Evaluasi Tepung Bungkil Biji Karet Difermentasi Cairan Rumen Domba pada Pakan Ikan Patin. Jurnal Akuakultur Indonesia, 13 (2): 146-151.

Tim Perikanan WWF-Indonesia. 2015. Budidaya Ikan Patin Siam (Pangasius hypophthalmus) Sistem Kolam, Karamba Jaring Tancap dan Karamba Jaring Apung. Edisi 1, WWF-Indonesia, Jakarta. 41 hlm.

Wardhani, L.K., M. Safrizal dan A. Chairi. 2011. Optimasi Komposisi Bahan Pakan Ikan Air Tawar menggunakan Metode Multi-Objective Genetic Algorithm. Seminar Nasional Aplikasi Teknologi Informasi, 112117.

Zonneveld, N., E.A. Huisman dan J.H. Boon. 1991.Prinsip-prinsip Budidaya Ikan. Gramedia Pustaka Utama, Jakarta. 336 hlm. 